\title{
Reducing the Extinction Risk of Populations Threatened by Infectious Diseases
}

\author{
Gael L. Glassock ${ }^{1}(0)$, Catherine E. Grueber ${ }^{1}$, Katherine Belov ${ }^{1}$ and Carolyn J. Hogg ${ }^{1,2, *}$ \\ 1 School of Life \& Environmental Sciences, The University of Sydney, Sydney, NSW 2006, Australia; \\ ggla5270@uni.sydney.edu.au (G.L.G.); catherine.grueber@sydney.edu.au (C.E.G.); \\ kathy.belov@sydney.edu.au (K.B.) \\ 2 San Diego Zoo Global, San Diego, CA 92101, USA \\ * Correspondence: carolyn.hogg@sydney.edu.au; Tel.: +61-2-8627-4896
}

check for

updates

Citation: Glassock, G.L.; Grueber, C.E.; Belov, K.; Hogg, C.J. Reducing the Extinction Risk of Populations Threatened by Infectious Diseases. Diversity 2021, 13, 63. https:// doi.org/10.3390/d13020063

Academic Editor: Michael Wink

Received: 30 November 2020

Accepted: 2 February 2021

Published: 4 February 2021

Publisher's Note: MDPI stays neutral with regard to jurisdictional claims in published maps and institutional affiliations.

Copyright: (C) 2021 by the authors Licensee MDPI, Basel, Switzerland. This article is an open access article distributed under the terms and conditions of the Creative Commons Attribution (CC BY) license (https:// creativecommons.org/licenses/by/ $4.0 /)$.

\begin{abstract}
Extinction risk is increasing for a range of species due to a variety of threats, including disease. Emerging infectious diseases can cause severe declines in wild animal populations, increasing population fragmentation and reducing gene flow. Small, isolated, host populations may lose adaptive potential and become more susceptible to extinction due to other threats. Management of the genetic consequences of disease-induced population decline is often necessary. Whilst disease threats need to be addressed, they can be difficult to mitigate. Actions implemented to conserve the Tasmanian devil (Sarcophilus harrisii), which has suffered decline to the deadly devil facial tumour disease (DFTD), exemplify how genetic management can be used to reduce extinction risk in populations threatened by disease. Supplementation is an emerging conservation technique that may benefit populations threatened by disease by enabling gene flow and conserving their adaptive potential through genetic restoration. Other candidate species may benefit from genetic management via supplementation but concerns regarding outbreeding depression may prevent widespread incorporation of this technique into wildlife disease management. However, existing knowledge can be used to identify populations that would benefit from supplementation where risk of outbreeding depression is low. For populations threatened by disease and, in situations where disease eradication is not an option, wildlife managers should consider genetic management to buffer the host species against inbreeding and loss of genetic diversity.
\end{abstract}

Keywords: genetic rescue; genetic restoration; supplementation; disease; genetic diversity; inbreeding; conservation

\section{Introduction}

Species extinction is a serious and pressing environmental challenge [1]. Loss of biodiversity disrupts ecosystem functioning, damages ecosystem services, and impacts human wellbeing $[2,3]$. Along with habitat fragmentation, small population sizes, invasive species, and climate change, emerging infectious diseases (hereafter diseases) contribute to species' decline [4,5]. Whilst there are no known instances of species extinction solely due to disease, black-footed ferrets (Mustela nigripes), Polynesian tree snails (Partula nodosa), Hawaiian honeycreepers (Carduelinae), African lions (Panthera leo), and American chestnuts (Castanea dentata) are some of the species that have experienced population crashes due to disease [6,7]. By decreasing the size of host populations, disease outbreaks can reduce their fitness and adaptability, predisposing them to extinction from other threats $[4,5,8]$. The reduced viability of disease-affected populations occurs because small populations are susceptible to inbreeding and genetic drift, which can result in increased homozygosity, fixation of deleterious alleles, and loss of genetic diversity [9-12]. Fragmented habitats can further exacerbate the impact of disease by reducing the movement of individuals between populations [13]. Whilst disease is a known threatening process that contributes to the endangerment and extinction of species [4,5], it can be difficult to mitigate. 
Current efforts to reduce the impact of diseases are generally focused on direct interventions, such as vaccines and/or host treatments [14]. Human intervention using these management practices can be successful in preserving populations affected by disease [5,14]. For example, the Arctic fox (Vulpes lagopus) variant of rabies was eradicated in eastern Ontario, Canada, following delivery of an oral rabies vaccine [15]. In contrast, some diseases are difficult to eradicate [16]. It is currently not possible to eliminate the devastating amphibian pathogen, chytrid fungus (Batrachochytrium dendrobatidis), due to environmental reservoirs and multiple host species sustaining the pathogen within the environment [17]. As a result, current management practices may limit the impact of a disease, but not eradicate it. Therefore, what should happen when it is not possible to directly reduce the prevalence and impact of a disease? Host populations may recover if a treatment is developed or pathogen-host coevolution occurs $[18,19]$. However, until some degree of pathogen immunity emerges, whether naturally or via human intervention such as a vaccine, many populations that are suffering significant disease outbreaks remain vulnerable and at low densities. Repopulating an area with disease-free individuals following disease-induced local population extinction has been successful in some instances [20]. However, this method is often unrealistic because it is dependent on the existence of a healthy source population. We suggest that, when pathogen eradication is not a viable management strategy, an alternative to preventing population extinctions is to genetically manage host populations until the disease can be more effectively controlled.

\section{The Tasmanian Devil}

\subsection{Devil Facial Tumour Disease (DFTD)}

Most infectious diseases are caused by pathogens, an organism capable of being transmitted from host-to-host where it causes disease. However, disease threats come in many forms. Tasmanian devils (Sarcophilus harrisii) are an example of a species that has suffered widespread decline following the outbreak of a disease. Endemic to the island state of Tasmania, devils are the world's largest surviving carnivorous marsupial. They are threatened by devil facial tumour disease (DFTD), which is a transmissible cancer, where the cancer cell line is the infectious agent and is passed as an allograft between individuals [21]. DFTD is characterised by large, ulcerating facial tumours [22], and is nearly always fatal $[23,24]$. Since DFTD was first detected in the mid-1990s, devil numbers have declined by 80 percent in the wild [25]. Precocial breeding by one-year-old females appears to be maintaining devil populations, despite the presence of DFTD [25,26]. However, contemporary modelling has shown that many of these populations are susceptible to small population pressures, including inbreeding [27], making them less adaptable and more vulnerable to other threatening processes. Tasmanian devils are listed as endangered both internationally on the International Union for Conservation of Nature (IUCN) Red List [28], and nationally under the Environment Protection and Biodiversity Conservation Act 1999, and require management to mitigate the threat of DFTD and to maintain the species in the landscape. Although immunisation trails have successfully induced an anti-DFTD antibody response in disease-free devils [29], research into a vaccine against DFTD is ongoing. As such, it is currently not possible to directly alleviate the negative impact DFTD has on devil populations in the wild.

\subsection{Genetic Managment}

The Save the Tasmanian Devil Program (STDP) is the official government response to DFTD. Established in 2003, one of its aims is to maintain devils and their ecological function in the wild. In the absence of effective treatments or vaccines for DFTD, the decision was made to manage devil populations in the presence of disease, rather than the disease itself as per general disease management strategies [30]. The remnant devil populations are fragmented, with most showing low connectivity [27,31], low genetic diversity [32] and population decline [25]; therefore, they are considered a candidate for genetic management. 
Translocations involve the human-mediated movement of individuals from one location to another, with the aim of supplying a population-level or species-level benefit [33]. Supplementation is a specific type of translocation where individuals are released into an existing population of conspecifics [33]. Supplementation offers a potential mechanism to artificially implement gene flow into disease populations and reverse the negative genetic changes that have occurred due to low population densities [34-38]. Introducing novel alleles via supplementation can improve allelic richness and increase genetic diversity, boosting the adaptability of the population and preventing deleterious alleles from becoming fixed [34,37,39-43]. Supplementation may also increase the number of individuals in the recipient population, buffering it against genetic drift and stochastic events [44,45]. Some have argued that the persistence of a few small, isolated populations in the absence of gene flow is evidence against the need for supplementing some populations with low genetic diversity $[46,47]$. However, these arguments are not supported by substantial empirical evidence and may be damaging to future conservation efforts [48]. Supplementation may be particularly beneficial for populations threatened by disease, because of gene flow into a host population, providing additional host alleles upon which selection can act [49].

The STDP established the Wild Devil Recovery Project in 2015 to investigate the use of supplementations to genetically manage declining wild devil populations [30]. Modelling has predicted that ongoing supplementation of DFTD-affected wild devil populations will prevent the loss of neutral rare alleles from the population, and increase the probability of population persistence over 50 years [27]. To date, six separate supplementations of four DFTD-affected wild devil populations have occurred, using devils sourced from a disease-free insurance metapopulation [50]. If available, genetic data should be used to select individuals for translocation to minimize inbreeding and maximize diversity [12]. Most devils in the insurance metapopulation have tissue samples taken which undergo reduced representation sequencing. These genetic data have been used to select devils for release; devils that best complement the wild sites by introducing novel alleles into the supplemented population [50]. Currently, the STDP and the University of Sydney are undertaking a large research study to investigate the impacts of these supplementations on population fitness and the prevalence of DFTD, with preliminary data showing positive signs [30]. Part of this research project includes measuring immune gene diversity, such as diversity at major histocompatibility complex (MHC) loci, in admixed devils following supplementation. Diversity at immune genes is important, because low MHC diversity in Tasmanian devils is believed to have contributed to the emergence and rapid transmission of DFTD [51].

Whilst the supplementations performed by the STDP aim to increase overall genetic variation, Kelly and Phillips (2015) suggest using a more aggressive approach, called targeted gene flow. Targeted gene flow introduces resistant alleles into a population by translocating individuals with beneficial adaptations. This technique has not been adopted into devil conservation efforts primarily because: (1) it is a relatively new concept with some aspects still speculative [52]; (2) investigations into genomic regions associated with DFTD resistance are still under investigation [53]; and (3) there are concerns that translocating individuals selected specifically for disease resistance may increase adaptability towards the disease but reduce future adaptive potential.

\subsection{Benefits of Supplementing Populations}

Performing supplementations to genetically manage populations threatened by disease is an emerging concept. Currently, there is little direct evidence regarding the ability of supplementations to reduce the extinction risk of diseased populations. Supplementation to preserve non-disease threatened populations [34,40-42] may provide some insight into the potential benefits of supplementing DFTD-affected devil populations.

The mountain pygmy-possum (Barramys parvus) is a prominent example of a threatened species, without specific known disease threats, which has benefitted from supplementation. The mountain pygmy-possum is a small, Australian marsupial, located 
within three, genetically distinct populations that have limited gene flow [42]. The Mount Buller population was under serious threat of extinction due to habitat clearing, which had reduced the size, genetic diversity, and fecundity of the population. To improve the demographic and genetic integrity of this population, it was supplemented with a small number of males $(n=11)$ sourced from one of the two other remaining populations, between 2011 and 2014 [44]. Following supplementation, the population exhibited a 68 percent growth in population size, increased genetic diversity, and integration of novel alleles into the gene pool over a five-year period [42]. There was evidence of hybrid fitness, seen in admixed individuals being larger and producing more offspring [42]. The response of the population to supplementation demonstrated that supplementation provided distinct genetic benefits to the Mount Buller population, as well as boosting population fitness and demographic parameters.

The response observed in the mountain pygmy-possum is indicative of genetic rescuean increase in population fitness (growth) of a population which is suffering inbreeding depression owing to the immigration of new alleles [43]. Genetic rescue occurred, partially due to the supplementation being performed in conjunction with efforts to restore the possum's degraded habitat [42]. These actions align with IUCN guidelines that, when performing supplementations, the threat that caused the population's decline should be minimized [33].

However, a key point of comparison between supplementing disease and non-diseaseaffected populations is that, whilst many threats to populations can at least be partially addressed, as noted above, disease threats can be difficult to mitigate. As such, population growth in diseased populations following supplementation is likely to be slower, resulting in genetic restoration. Genetic restoration is an increase in genetic variation and relative, but not absolute, fitness owing to the immigration of new alleles [43]. Whilst genetic restoration does not necessarily produce the same demographic recovery achieved by genetic rescue, it nevertheless boosts the diversity of the population and helps ensure its future adaptive potential. Measuring genetic change in a population following supplementation (e.g., inbreeding, and neutral and functional diversity) is a useful measure of supplementation success in populations threatened by disease.

For Tasmanian devils, this means that supplementing populations under the Wild Devil Recovery Project may not lead to significant demographic recovery due to the ongoing presence of disease, but may lead to genetic benefits for populations which are showing signs of increasing inbreeding [27]. At this time, it is undetermined if these supplementations will benefit or hinder the species' ability to co-evolve with the disease. Although evidence of a selective response in devils to DFTD has been inconsistent [53,54], the suggestion of possible evolutionary change in devil populations exposed to DFTD [53] has prompted concern that sourcing the released devils from the DFTD-free insurance population will be counter-productive for the evolution of host resistance to the disease [55]. It should be noted, however, that the insurance metapopulation has been acquiring orphan devils from diseased populations since 2009 [56,57], so much post-DFTD wild diversity is likely to be represented in the insurance metapopulation.

\section{Extending Principles Adopted in Tasmanian Devil Conservation Efforts to Other Populations Suffering from Disease}

\subsection{Genetic Management of Disease-Affected Populations}

Tasmanian devils are one of the few species primarily suffering from decline due to disease that have genetic management via supplementation incorporated into their conservation program. It is unfortunate that the genetic management of disease-threatened populations has not been more widely accepted, because other species impacted by disease could benefit from supplementation. For example, mountain yellow-legged frogs (Rana muscosa) have declined, in part, due to chytrid fungus [58]. They are currently listed as endangered by the IUCN [59]. There are nine small populations of frogs, persisting in southern California, U.S.A., that require management to avoid extinction [60]. These populations are structured and possess low within-population variation, indicating that the populations are genetically isolated [61]. Currently, there is no evidence of inbreed- 
ing within these populations [61]; however, given that gene flow between populations is limited, it may emerge. Implementing strategies, similar to those adopted in devil conservation efforts, could avoid loss of alleles due to genetic drift and inbreeding. Captive frogs involved in San Diego Zoo's successful breeding program [61] could potentially be an appropriate source of individuals for supplementation. Augmenting gene flow may reduce extinction risk in the mountain yellow-legged frog, and other species subject to significant disease-induced population decline, by maintaining genetic diversity and providing alternate alleles upon which selection can act.

\subsection{Fear of Failure}

There is a hesitancy to accept supplementation as a conservation strategy even in non-diseased populations [12]. From a genetic perspective, a primary perceived risk associated with supplementation is outbreeding depression [12]. Outbreeding depression occurs when the mixing of two genetically distinct populations leads to reduced fitness in hybrid offspring, due to the disruption of co-adapted gene complexes $[9,43]$. However, outbreeding depression is rare [62], and mainly seen when the mixed populations are highly divergent or show high genetic structure [12,62]. An example is the Tanta Mountain ibex (Capra ibex ibex), where a population was supplemented with individuals sourced from two related subspecies. Hybrids of the incumbent and introduced ibex showed altered reproductive habits that led to offspring death and population extinction [63]. To combat this, a decision-making framework has been developed to predict the likelihood of outbreeding depression occurring [64]. The outcome of mixing populations cannot be definitively known until post-supplementation, and therefore there is no guarantee that a supplementation will not have negative impacts. However, existing knowledge surrounding the probability of outbreeding depression $[12,62,64]$ and the characteristics of a suitable source population $[9,35]$ allows for better selection of candidates for supplementation. Coupled with the ever-increasing global production of wildlife genomes and modelling methods, we are in a better position than ever to predict the impacts of supplementation on threatened populations, both with and without disease.

Outbreeding depression is not the only risk that needs to be considered when making the decision about whether to supplement disease-threatened populations. Other concerns include the loss of local adaptations, loss of species purity due to mixing of gene pools, genetic replacement, and disease spread $[12,44]$. In situations where the disease threat is difficult to mitigate, conservation managers may be hesitant to release healthy individuals into the wild where they may be exposed to the disease, especially if the size of the disease-free source population is small. As conducted with the Tasmanian devil, modelling and simulations, such as population viability analyses, which incorporate the demographic effects of disease, can be useful to weigh risks and options when considering supplementation [27]. In addition, wildlife disease risk analyses offer a structured method to identify, prevent, and mitigate disease risks associated with supplementation prior to implementation [65].

A well-intentioned fear of doing harm may prevent supplementation being used to genetically manage populations threatened by disease. However, a decision to not implement genetic management, or other conservation actions, is still an active conservation action with its own ramifications $[12,17,36,42]$. For example, the decision was made to preserve the taxonomic integrity of the dusky seaside sparrow (Ammodramus maritimus nigrescens) rather than outcross the remaining individuals to a closely related subspecies [66]. This decision resulted in a detrimental outcome: the species became extinct, and the unique diversity that otherwise might have been preserved was lost. This does not necessarily mean that this outcrossing event would have prevented the extinction of the dusky seaside sparrow, but we shall never know. Instead, this example encourages us to recognize that species have become extinct after active decisions not to intervene were made.

There will always be some degree of risk associated with implementing a management strategy. However, if supplementation is done to serve a conservation purpose in response 
to genetic isolation, inbreeding, and low genetic diversity, the rewards will often outweigh the risks, especially when facing the ultimate risk of species extinction. For a diseased population that is declining, the fear of failure needs to be weighed against the potential consequences of inbreeding, loss of genetic diversity, and decline in adaptive potential if the decision to not supplement the population is made.

\section{Conclusions}

There are a range of threatened species, and subsequently a range of management actions to ensure their persistence. For many species suffering infectious diseases, conservation management actions are further complicated by the disease. Here, we suggest that genetically managing disease-affected populations may assist in reducing their extinction risk when the disease threat cannot be easily mitigated. This is not a definitive solution but may buy the species time to co-evolve with their disease. As has been implemented with the Tasmanian devil, supplementation may lead to genetic restoration of these diseasethreatened populations, alleviating loss of genetic diversity and maintaining their adaptive potential. Although it is possible that not all populations are suitable for this type of genetic management [64], these populations can generally be identified by preliminary screening [12]. In addition, the primary genetic risk of outbreeding depression is rare, usually manageable, and often less threatening than the extinction risk these populations face in the absence of augmented gene flow [12]. Future supplementations should be performed in conjunction with long-term monitoring to expand the existing knowledge of genetic rescue/restoration activities and gather empirical evidence of its success in diseased populations. Rather than delaying action due to a fear of provoking harmful consequences, genetic management should be recognized as a potentially beneficial conservation technique, allowing for the development of more effective management practices where action rather than inaction is favoured.

Author Contributions: Conceptualization, G.L.G., C.E.G., K.B. and C.J.H.; investigation, G.L.G.; resources, G.L.G.; writing—original draft preparation, G.L.G.; writing—review and editing, C.E.G., K.B. and C.J.H.; supervision, C.E.G., K.B. and C.J.H.; project administration, C.J.H.; funding acquisition, C.E.G., K.B. and C.J.H. All authors have read and agreed to the published version of the manuscript.

Funding: This research was funded by the Australian Research Council Linkage (LP180100244).

Acknowledgments: Thanks to members of the Australasian Wildlife Genomics Group who participated in the many discussions regarding genetic rescue in the presence of disease.

Conflicts of Interest: The authors declare no conflict of interest.

\section{References}

1. Ceballos, G.; Ehrlich, P.R.; Barnosky, A.D.; García, A.; Pringle, R.M.; Palmer, T.M. Accelerated modern human-induced species losses: Entering the sixth mass extinction. Sci. Adv. 2015, 1, e1400253. [CrossRef]

2. Díaz, S.; Fargione, J.; Chapin, F.S.; Tilman, D. Biodiversity Loss Threatens Human Well-Being. PLoS Biol. 2006, 4, e277. [CrossRef]

3. Mace, G.M.; Norris, K.; Fitter, A.H. Biodiversity and ecosystem services: A multilayered relationship. Trends Ecol. Evol. 2012, 27, 19-26. [CrossRef]

4. McKnight, D.T.; Schwarzkopf, L.; Alford, R.A.; Bower, D.S.; Zenger, K.R. Effects of emerging infectious diseases on host population genetics: A review. Conserv. Genet. 2017, 18, 1235-1245. [CrossRef]

5. De Castro, F.; Bolker, B. Mechanisms of disease-induced extinction. Ecol. Lett. 2005, 8, 117-126. [CrossRef]

6. Cunningham, A.A.; Daszak, P.; Wood, J.L.N. One Health, emerging infectious diseases and wildlife: Two decades of progress? Philosophical transactions. Biol. Sci. 2017, 372, 20160167. [CrossRef]

7. Douglass, F.J.; Harmony, J.D.; Nelson, C.D. A conceptual framework for restoration of threatened plants: The effective model of American chestnut (Castanea dentata) reintroduction. New Phytol. 2013, 197, 378-393.

8. Deem, S.L.; Karesh, W.B.; Weisman, W. Putting Theory into Practice: Wildlife Health in Conservation; Blackwell Science Inc: Boston, MA, USA, 2001; pp. 1224-1233.

9. Edmands, S. Between a rock and a hard place: Evaluating the relative risks of inbreeding and outbreeding for conservation and management. Mol. Ecol. 2006, 16, 463-475. [CrossRef]

10. Huisman, J.; Kruuk, L.E.B.; Ellis, P.A.; Clutton-Brock, T.H.; Pemberton, J.M. Inbreeding depression across the lifespan in a wild mammal population. Proc. Natl. Acad. Sci. USA 2016, 113, 3585-3590. [CrossRef] [PubMed] 
11. Wisely, S.M.; Ryder, O.A.; Santymire, R.M.; Engelhardt, J.F.; Novak, B.J. A Road Map for 21st Century Genetic Restoration: Gene Pool Enrichment of the Black-Footed Ferret. J. Hered. 2015, 106, 581-592. [CrossRef] [PubMed]

12. Ralls, K.; Ballou, J.D.; Dudash, M.R.; Eldridge, M.D.B.; Fenster, C.B.; Lacy, R.C.; Sunnucks, P.; Frankham, R. Call for a Paradigm Shift in the Genetic Management of Fragmented Populations. Conserv. Lett. 2017, 11, e12412. [CrossRef]

13. Hamish, M.; Andy, D. Disease, habitat fragmentation and conservation. Proc. R. Soc. B Biol. Sci. 2002, 269, $2041-2049$.

14. Joseph, M.B.; Mihaljevic, J.R.; Arellano, A.L.; Kueneman, J.G.; Preston, D.L.; Cross, P.C.; Johnson, P.T.J. Taming wildlife disease: Bridging the gap between science and management. J. Appl. Ecol. 2013, 50, 702-712. [CrossRef]

15. MacInnes, C.D.; Smith, S.M.; Tinline, R.; Ayers, N.R.; Bachmann, P.; Ball, D.G.A.; Calder, L.A.; Crosgrey, S.J.; Fielding, C.; Hauschildt, P.; et al. Elimination of rabies from red foxes in eastern ontario. J. Wildl. Dis. 2001, 37, 119-132. [CrossRef] [PubMed]

16. Portier, J.; Ryser-Degiorgis, M.-P.; Hutchings, M.R.; Monchâtre-Leroy, E.; Richomme, C.; Larrat, S.; Van Der Poel, W.H.M.; Dominguez, M.; Linden, A.; Santos, P.T.; et al. Multi-host disease management: The why and the how to include wildlife. BMC Vet. Res. 2019, 15, 1-11. [CrossRef] [PubMed]

17. Scheele, B.C.; Hunter, D.A.; Grogan, L.F.; Berger, L.; Kolby, J.E.; McFadden, M.S.; Marantelli, G.; Skerratt, L.F.; Driscoll, D.A. Interventions for Reducing Extinction Risk in Chytridiomycosis-Threatened Amphibians. Conserv. Biol. 2014, 28, 1195-1205. [CrossRef]

18. Scheele, B.C.; Foster, C.N.; Hunter, D.A.; Lindenmayer, D.B.; Schmidt, B.R.; Heard, G.W. Living with the enemy: Facilitating amphibian coexistence with disease. Biol. Conserv. 2019, 236, 52-59. [CrossRef]

19. Boots, M.; Best, A.; Miller, M.R.; White, A. The role of ecological feedbacks in the evolution of host defence: What does theory tell us? Philos. Trans. R. Soc. B Biol. Sci. 2008, 364, 27-36. [CrossRef]

20. Jachowski, D.S.; Gitzen, R.A.; Grenier, M.B.; Holmes, B.; Millspaugh, J.J. The importance of thinking big: Large-scale prey conservation drives black-footed ferret reintroduction success. Biol. Conserv. 2011, 144, 1560-1566. [CrossRef]

21. Pearse, A.M.; Swift, K. Allograft theory: Transmission of devil facial-tumour disease. Nature 2006, 439, 549. [CrossRef]

22. Pye, R.J.; Pemberton, D.; Tovar, C.; Tubio, J.M.C.; Dun, K.A.; Fox, S.; Darby, J.; Hayes, D.; Knowles, G.W.; Kreiss, A.; et al. A second transmissible cancer in Tasmanian devils. Proc. Natl. Acad. Sci. USA 2015, 113, 374-379. [CrossRef]

23. Hawkins, C.; Baars, C.; Hesterman, H.; Hocking, G.; Jones, M.; Lazenby, B.; Mann, D.; Mooney, N.; Pemberton, D.; Pyecroft, S.; et al. Emerging disease and population decline of an island endemic, the Tasmanian devil Sarcophilus harrisii. Biol. Conserv. 2006, 131, 307-324. [CrossRef]

24. Pye, R.; Hamede, R.; Siddle, H.V.; Caldwell, A.; Knowles, G.W.; Swift, K.; Kreiss, A.; Jones, M.E.; Lyons, A.B.; Woods, G.M. Demonstration of immune responses against devil facial tumour disease in wild Tasmanian devils. Biol. Lett. 2016, 12, 20160553. [CrossRef] [PubMed]

25. Lazenby, B.; Tobler, M.W.; Brown, W.E.; Hawkins, C.E.; Hocking, G.J.; Hume, F.; Huxtable, S.; Iles, P.; Jones, M.E.; Lawrence, C.; et al. Density trends and demographic signals uncover the long-term impact of transmissible cancer in Tasmanian devils. J. Appl. Ecol. 2018, 55, 1368-1379. [CrossRef]

26. Jones, M.E.; Cockburn, A.; Hamede, R.; Hawkins, C.; Hesterman, H.; Lachish, S.; Mann, D.; McCallum, H.; Pemberton, D. Life-history change in disease-ravaged Tasmanian devil populations. Proc. Natl. Acad. Sci. USA 2008, 105, 10023-10027. [CrossRef]

27. Grueber, C.E.; Fox, S.; McLennan, E.A.; Gooley, R.M.; Pemberton, D.; Hogg, C.J.; Belov, K. Complex problems need detailed solutions: Harnessing multiple data types to inform genetic management in the wild. Evol. Appl. 2018, 12, 280-291. [CrossRef] [PubMed]

28. Hawkins, C.E.; McCallum, H.; Mooney, N.; Jones, M.; Holdsworth, M. Sarcophilus Harrisii; The IUCN Red List of Threatened Species: Cambridge, UK, 2008.

29. Pye, R.; Patchett, A.; McLennan, E.; Thomson, R.; Carver, S.; Fox, S.; Pemberton, D.; Kreiss, A.; Morelli, A.B.; Silva, A. Immunization strategies producing a humoral IgG immune response against devil facial tumor disease in the majority of Tasmanian devils destined for wild release. Front. Immunol. 2018, 9, 259. [CrossRef]

30. Fox, S.; Seddon, P.J. Wild devil recovery: Managing devils in the presence of disease. In Saving the Tasmanian Devil Recovery through Science-Based Management; Hogg, C., Fox, S., Pemberton, D., Belov, K., Eds.; CSIRO: Victoria, Australia, 2019.

31. Lachish, S.; Miller, K.J.; Storfer, A.; Goldizen, A.W.; Jones, M.E. Evidence that disease-induced population decline changes genetic structure and alters dispersal patterns in the Tasmanian devil. Heredity 2010, 106, 172-182. [CrossRef]

32. Miller, W.; Hayes, V.M.; Ratan, A.; Petersen, D.C.; Wittekindt, N.E.; Miller, J.; Walenz, B.; Knight, J.; Qingyu, W.; Zhao, F.; et al. Genetic diversity and population structure of the endangered marsupial Sarcophilus harrisii (Tasmanian devil). Proc. Natl. Acad. Sci. USA 2011, 108, 12348-12353. [CrossRef]

33. IUCN. Guidlines for Reintroductions and Other Conservation Translocations; Commission, I.S.S., Ed.; IUCN: Gland, Switzerland, 2013.

34. Hogg, J.T.; Forbes, S.H.; Steele, B.M.; Luikart, G. Genetic rescue of an insular population of large mammals. Proc. R. Soc. B Boil. Sci. 2006, 273, 1491-1499. [CrossRef]

35. Kronenberger, J.A.; Gerberich, J.C.; Fitzpatrick, S.W.; Broder, E.D.; Angeloni, L.M.; Funk, W.C. An experimental test of alternative population augmentation scenarios. Conserv. Biol. 2018, 32, 838-848. [CrossRef]

36. Stowell, S.M.L.; Pinzone, C.A.; Martin, A.P. Overcoming barriers to active interventions for genetic diversity. Biodivers. Conserv. 2017, 16, 613-1765. [CrossRef]

37. Robinson, Z.L.; Coombs, J.A.; Hudy, M.; Nislow, K.H.; Letcher, B.H.; Whiteley, A.R. Experimental test of genetic rescue in isolated populations of brook trout. Mol. Ecol. 2017, 26, 4418-4433. [CrossRef] 
38. Hedrick, P.W.; Garcia-Dorado, A. Understanding Inbreeding Depression, Purging, and Genetic Rescue. Trends Ecol. Evol. 2016, 31, 940-952. [CrossRef]

39. Heber, S.; Varsani, A.; Kuhn, S.; Girg, A.; Kempenaers, B.; Briskie, J. The genetic rescue of two bottlenecked South Island robin populations using translocations of inbred donors. Proc. Biol. Sci. 2013, 280, 20122228. [CrossRef]

40. Hedrick, P.W.; Fredrickson, R. Genetic rescue guidelines with examples from Mexican wolves and Florida panthers. Conserv. Genet. 2009, 11, 615-626. [CrossRef]

41. Johnson, W.E.; Onorato, D.; Roelke, M.E.; Land, E.D.; Cunningham, M.; Belden, R.C.; McBride, R.; Jansen, D.; Lotz, M.; Shindle, D.; et al. Genetic Restoration of the Florida Panther. Science 2010, 329, 1641-1645. [CrossRef] [PubMed]

42. Weeks, A.R.; Heinze, D.; Perrin, L.; Stoklosa, J.; Hoffmann, A.A.; Van Rooyen, A.; Kelly, T.; Mansergh, I. Genetic rescue increases fitness and aids rapid recovery of an endangered marsupial population. Nat. Commun. 2017, 8, 1-6. [CrossRef] [PubMed]

43. Whiteley, A.R.; Fitzpatrick, S.W.; Funk, W.C.; Tallmon, D.A. Genetic rescue to the rescue. Trends Ecol. Evol. 2015, 30, 42-49. [CrossRef] [PubMed]

44. Weeks, A.R.; Sgro, C.M.; Young, A.G.; Frankham, R.; Mitchell, N.J.; Miller, K.A.; Byrne, M.; Coates, D.J.; Eldridge, M.D.B.; Sunnucks, P.; et al. Assessing the benefits and risks of translocations in changing environments: A genetic perspective. Evol. Appl. 2011, 4, 709-725. [CrossRef] [PubMed]

45. Hufbauer, R.; Szúcs, M.; Kasyon, E.; Youngberg, C.; Koontz, M.J.; Richards, C.M.; Tuff, T.; Melbourne, B.A. Three types of rescue can avert extinction in a changing environment. Proc. Natl. Acad. Sci. USA 2015, 112, 10557-10562. [CrossRef] [PubMed]

46. Robinson, J.; Brown, C.; Kim, B.Y.; Lohmueller, K.E.; Wayne, R.K. Purging of Strongly Deleterious Mutations Explains Long-Term Persistence and Absence of Inbreeding Depression in Island Foxes. Curr. Biol. 2018, 28, 3487-3494.e4. [CrossRef]

47. Robinson, J.A.; Vecchyo, D.O.-D.; Fan, Z.; Kim, B.Y.; Vonholdt, B.M.; Marsden, C.D.; Lohmueller, K.E.; Wayne, R.K. Genomic Flatlining in the Endangered Island Fox. Curr. Biol. 2016, 26, 1183-1189. [CrossRef] [PubMed]

48. Ralls, K.; Sunnucks, P.; Lacy, R.C.; Frankham, R. Genetic rescue: A critique of the evidence supports maximizing genetic diversity rather than minimizing the introduction of putatively harmful genetic variation. Biol. Conserv. 2020, 251, 108784. [CrossRef]

49. Gandon, S.; Michalakis, Y. Local adaptation, evolutionary potential and host-parasite coevolution: Interactions between migration, mutation, population size and generation time. J. Evol. Biol. 2002, 15, 451-462. [CrossRef]

50. Hogg, C.; McLennan, E.; Wise, P.; Lee, A.; Pemberton, D.; Fox, S.; Belov, K.; Grueber, C. Preserving the demographic and genetic integrity of a single source population during multiple translocations. Biol. Conserv. 2020, 241, 108318. [CrossRef]

51. Peel, E.; Belov, K. Lessons learnt from the Tasmanian devil facial tumour regarding immune function in cancer. Mamm. Genome 2018, 29, 731-738. [CrossRef]

52. Kelly, E.; Phillips, B.L. Targeted gene flow for conservation. Conserv. Biol. 2016, 30, 259-267. [CrossRef]

53. Epstein, B.; Jones, M.; Hamede, R.; Hendricks, S.; McCallum, H.; Murchison, E.P.; Schönfeld, B.; Wiench, C.; Hohenlohe, P.; Storfer, A. Rapid evolutionary response to a transmissible cancer in Tasmanian devils. Nat. Commun. 2016, 7, 1-7. [CrossRef]

54. Brüniche-Olsen, A.; Austin, J.J.; Jones, M.E.; Holland, B.R.; Burridge, C.P. Detecting Selection on Temporal and Spatial Scales: A Genomic Time-Series Assessment of Selective Responses to Devil Facial Tumor Disease. PLoS ONE 2016, 11, e0147875. [CrossRef]

55. Hohenlohe, P.A.; McCallum, H.I.; Jones, M.E.; Lawrance, M.F.; Hamede, R.K.; Storfer, A. Conserving adaptive potential: Lessons from Tasmanian devils and their transmissible cancer. Conserv. Genet. 2019, 20, 81-87. [CrossRef]

56. Hogg, C.J.; Lee, A.V.; Hibbard, C.J. Managing a metapopulation: Intensive to wild and all the places in between. In Saving the Tasmanian devil: Recovery through Science-Based Management; CSIRO: Victoria, Australia, 2019.

57. Hogg, C.J.; Lee, A.V.; Srb, C.; Hibbard, C. Metapopulation management of an Endangered species with limited genetic diversity in the presence of disease: The Tasmanian devil Sarcophilus harrisii. Int. Zoo Yearb. 2016, 51, 137-153. [CrossRef]

58. Gary, M.F.; Green, D.E.; Joyce, E.L. Oral Chytridiomycosis in the Mountain Yellow-Legged Frog (Rana muscosa). Copeia 2001, $2001,945-953$.

59. Hammerson, G. Rana Muscosa; The IUCN Red List of Threatened Species: Cambridge, UK, 2008.

60. Backlin, A.R.; Hitchcock, C.J.; Gallegos, E.A.; Yee, J.L.; Fisher, R.N. The precarious persistence of the Endangered Sierra Madre yellow-legged frog Rana muscosa in southern California, USA. Oryx 2013, 49, 157-164. [CrossRef]

61. Schoville, S.D.; Tustall, T.S.; Vredenburg, V.T.; Backlin, A.R.; Gallegos, E.; Wood, D.A.; Fisher, R.N. Conservation genetics of evolutionary lineages of the endangered mountain yellow-legged frog, Rana muscosa (Amphibia: Ranidae), in southern California. Biol. Conserv. 2011, 144, 2031-2040. [CrossRef]

62. Byrne, P.G.; Silla, A.J. An experimental test of the genetic consequences of population augmentation in an amphibian. Conserv. Sci. Pract. 2020, 2, 1-11. [CrossRef]

63. Templeton, A.; Hemmer, H.; Mace, G.M.; Seal, U.S.; Shields, W.M.; Woodruff, D.S. Local adaptation, coadaptation, and population boundaries. Zoo Biol. 1986, 5, 115-125. [CrossRef]

64. Frankham, R.; Ballou, J.D.; Eldridge, M.D.B.; Lacy, R.C.; Ralls, K.; Dudash, M.R.; Fenster, C.B. Predicting the Probability of Outbreeding Depression. Conserv. Biol. 2011, 25, 465-475. [CrossRef] [PubMed]

65. Hartley, M.; Sainsbury, A. Methods of Disease Risk Analysis in Wildlife Translocations for Conservation Purposes. EcoHealth 2017, 14, 16-29. [CrossRef]

66. Zink, R.M.; Kale, H.W. Conservation genetics of the extinct dusky seaside sparrow Ammodramus maritimus nigrescens. Biol. Conserv. 1995, 74, 69-71. [CrossRef] 